\title{
Modelled black carbon radiative forcing and atmospheric lifetime in AeroCom Phase II constrained by aircraft observations
}

\author{
B. H. Samset ${ }^{1}$, G. Myhre ${ }^{1}$, A. Herber ${ }^{2}$, Y. Kondo ${ }^{3}$, S.-M. Li ${ }^{4}$, N. Moteki ${ }^{3}$, M. Koike ${ }^{3}$, N. Oshima ${ }^{5}$, J. P. Schwarz ${ }^{6,19}$, \\ Y. Balkanski ${ }^{7}$, S. E. Bauer ${ }^{8}$, N. Bellouin ${ }^{9, *}$, T. K. Berntsen ${ }^{1}$, H. Bian ${ }^{10}$, M. Chin ${ }^{11}$, T. Diehl ${ }^{11,20,{ }^{* *}}$, R. C. Easter ${ }^{12}$,

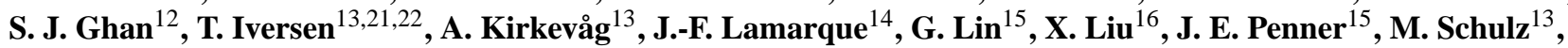 \\ Ø. Seland ${ }^{13}$, R. B. Skeie ${ }^{1}$, P. Stier ${ }^{17}$, T. Takemura ${ }^{18}$, K. Tsigaridis ${ }^{8}$, and K. Zhang ${ }^{12}$ \\ ${ }^{1}$ Center for International Climate and Environmental Research - Oslo (CICERO), Oslo, Norway \\ ${ }^{2}$ Alfred Wegener Institute for Polar and Marine Research in the Helmholtz Association, Bürgermeister-Smidt-Straße 20, \\ 27568 Bremerhaven, Germany \\ ${ }^{3}$ Department of Earth and Planetary Science, Graduate School of Science, University of Tokyo, Tokyo, Japan \\ ${ }^{4}$ Air Quality Research Division, Science and Technology Branch, Environment Canada, 4905 Dufferin Street, Toronto, \\ Ontario, M3H 5T4, Canada \\ ${ }^{5}$ Meteorological Research Institute, Tsukuba, Ibaraki Japan \\ ${ }^{6}$ Chemical Sciences Division, Earth System Research Laboratory, National Oceanic and Atmospheric Administration, \\ Boulder, CO, USA \\ ${ }^{7}$ Laboratoire des Sciences du Climat et de l'Environnement, CEA-CNRS-UVSQ, Gif-sur-Yvette, France \\ ${ }^{8}$ NASA Goddard Institute for Space Studies and Columbia Earth Institute, New York, NY, USA \\ ${ }^{9}$ Met Office Hadley Centre, Exeter, UK \\ ${ }^{10}$ Joint Center for Earth Systems Technology, University of Maryland Baltimore County, MD, USA \\ ${ }^{11}$ NASA Goddard Space Flight Center, Greenbelt, MD, USA \\ ${ }^{12}$ Pacific Northwest National Laboratory, Richland, WA, USA \\ ${ }^{13}$ Norwegian Meteorological Institute, Oslo, Norway \\ ${ }^{14}$ NCAR Earth System Laboratory, National Center for Atmospheric Research, Boulder, CO, USA \\ ${ }^{15}$ Department of Atmospheric, Oceanic, and Space Sciences, University of Michigan, Ann Arbor, MI, USA \\ ${ }^{16}$ Department of Atmospheric Science, University of Wyoming, Laramie, WY, USA \\ ${ }^{17}$ Department of Physics, University of Oxford, Oxford, UK \\ ${ }^{18}$ Research Institute for Applied Mechanics, Kyushu University, Fukuoka, Japan \\ ${ }^{19}$ Cooperative Institute for Research in Environmental Sciences, University of Colorado Boulder, Boulder, CO, USA \\ ${ }^{20}$ Universities Space Research Association, Columbia, MD, USA \\ ${ }^{21}$ Department of Geosciences, University of Oslo, Oslo, Norway \\ ${ }^{22}$ ECMWF, Shinfield Park, RG2 9AX, Reading, UK \\ * Department of Meteorology, University of Reading, Reading, UK \\ ***aropean Commission at the Joint Research Center, Ispra, Italy
}

Correspondence to: B. H. Samset (b.h.samset@ cicero.oslo.no)

Received: 30 May 2014 - Published in Atmos. Chem. Phys. Discuss.: 4 August 2014

Revised: 3 October 2014 - Accepted: 27 October 2014 - Published: 27 November 2014 
Abstract. Atmospheric black carbon (BC) absorbs solar radiation, and exacerbates global warming through exerting positive radiative forcing (RF). However, the contribution of $\mathrm{BC}$ to ongoing changes in global climate is under debate. Anthropogenic $\mathrm{BC}$ emissions, and the resulting distribution of $\mathrm{BC}$ concentration, are highly uncertain. In particular, longrange transport and processes affecting $\mathrm{BC}$ atmospheric lifetime are poorly understood. Here we discuss whether recent assessments may have overestimated present-day $\mathrm{BC}$ radiative forcing in remote regions. We compare vertical profiles of $\mathrm{BC}$ concentration from four recent aircraft measurement campaigns to simulations by 13 aerosol models participating in the AeroCom Phase II intercomparison. An atmospheric lifetime of $\mathrm{BC}$ of less than 5 days is shown to be essential for reproducing observations in remote ocean regions, in line with other recent studies. Adjusting model results to measurements in remote regions, and at high altitudes, leads to a $25 \%$ reduction in AeroCom Phase II median direct BC forcing, from fossil fuel and biofuel burning, over the industrial era. The sensitivity of modelled forcing to BC vertical profile and lifetime highlights an urgent need for further flight campaigns, close to sources and in remote regions, to provide improved quantification of $\mathrm{BC}$ effects for use in climate policy.

\section{Introduction}

As an absorber of solar radiation, anthropogenic BC emissions can contribute positively to global radiative forcing through the aerosol direct effect, they can affect clouds through the aerosol indirect and semidirect effects, change albedo of snow and ice, and influence precipitation by changing atmospheric stability and the surface energy balance (Myhre et al., 2013a; Ramanathan and Carmichael, 2008; Haywood and Shine, 1995). Presently both the magnitude of anthropogenic $\mathrm{BC}$ emissions and the resulting global distribution of $\mathrm{BC}$ concentrations are highly uncertain. In particular the vertical profile of $\mathrm{BC}$ concentration, which strongly affects its total impact on the energy balance of the atmosphere, is poorly constrained (Koffi et al., 2012; Textor et al., 2007; Samset et al., 2013). Comparisons of measurements with model results, with emphasis both on total BC mass, spatio-temporal distribution and vertical structure are therefore essential for constraining estimates of $\mathrm{BC}$ effects on climate.

The IPCC AR5 (Boucher et al., 2013) assessed the direct aerosol effect radiative forcing due to anthropogenic BC (defined here as $\mathrm{BC}$ from anthropogenic fossil fuel and biofuel sources, $\mathrm{BC} F F+\mathrm{BF}$ ) to be +0.40 [range: +0.05 to $+0.80] \mathrm{W} \mathrm{m}^{-2}$ over the period 1750-2010. That assessment took into account both model-based and observational studies. Recently, Phase II of the AeroCom model intercomparison project (Myhre et al., 2013b) also evaluated BC FF + BF radiative forcing (RF), based purely on 15 global aerosol models (Myhre et al., 2013b), and found it to be +0.23 $[+0.06$ to +0.48$] \mathrm{W} \mathrm{m}^{-2}$. The uncertainty ranges $(5-95 \%)$ show that $\mathrm{BC}$ is still a major contributor to the total uncertainty on anthropogenic RF. Further, it has recently been shown that, because the direct RF per unit mass BC increases strongly with altitude (Ban-Weiss et al., 2011; Zarzycki and Bond, 2010; Samset and Myhre, 2011), the diversity in modelled vertical profiles of $\mathrm{BC}$ concentration in the AeroCom Phase II models may account for up to $50 \%$ of the model diversity in anthropogenic BC RF (Samset et al., 2013). Climate model simulations, however, indicate that, while direct $\mathrm{BC}$ forcing strengthens with altitude, its climate efficacy may decrease, i.e. the surface temperature response to $\mathrm{BC}$ in the middle and upper troposphere may be small or even negative (Ban-Weiss et al., 2011; Flanner, 2013). Further, Samset et al. (2014) concluded that an upward adjustment on the model-based uncertainty on total aerosol forcing may be necessary, in an analysis that looked at multimodel variability in per-species aerosol burdens and optical parameters. BC forcing diversity was found to be a significant component in this analysis.

Recently, several single-model studies have investigated other factors that may underlie the intermodel variability in AeroCom Phase II, or assessed its multimodel mean results in light of observations. For example, Wang et al. (2014a) compared results from the GEOS-Chem model (http: //geos-chem.org) with results from the HIPPO flight campaign, and concluded that to reproduce HIPPO, more wet removal was required than is represented in most present models. Based on this, and on revised estimates on direct RF of BC when taking HIPPO constraints (Schwarz et al., 2013) into account, they argue that previous model estimates may be biased high due to elevated $\mathrm{BC}$ concentrations in the free troposphere. Bauer et al. (2013) studied the atmospheric lifetime of $\mathrm{BC}$, which is a combined measure of transport and removal processes, by comparing simulations with the GISSMATRIX model to HIPPO (Bauer et al., 2010), using CMIP5 emissions. They found that under present-day conditions, BC lifetime should be no more than 4 days, which is significantly shorter than what is used in some present models. Hodnebrog et al. (2014) showed that such a reduction in lifetime, when combined with estimates of the impact from $\mathrm{BC}$ on atmospheric stability, can lead to major reductions in the global mean climate impact of $\mathrm{BC}$ emissions. Based on the above, it is natural to investigate both whether the full AeroCom Phase II RF estimate is biased high, as was found for GEOSChem, and what contribution to multimodel variability may be due to differences in modelled $\mathrm{BC}$ lifetime.

In the following, we compare vertical concentration profiles from the AeroCom Phase II models to recent aircraft campaigns. The results are used to set multimodel constraints on $\mathrm{BC}$ lifetime, and to find limits on the possible high bias of AeroCom Phase II BC RF if constraining to HIPPO results. 


\section{Methods}

\subsection{Flight data and $\mathrm{BC}$ definition}

We have used data from flight campaigns HIAPER Pole-toPole Observations (HIPPO) 1-5 (Schwarz et al., 2013), Arctic Research of the Composition of the Troposphere from Aircraft and Satellites (ARCTAS) SP2 (Jacob et al., 2010), Polar Airborne Measurements and Arctic Regional Climate Model Simulation Project (PAMARCMiP) (Herber et al., 2012; Stone et al., 2010) and Aerosol Radiative Forcing in East Asia (A-FORCE) (Oshima et al., 2012), see Table 1.

All flights measured $\mathrm{BC}$ concentrations using the single particle soot photometer (SP2) instrument (Schwarz et al., 2010). Hence, in the present work, "BC" in relation to measured data stands for "refractive BC (rBC)" as quantified by SP2, equivalent to properly measured elemental carbon (Kondo et al., 2011).

HIPPO 1-5 (Schwarz et al., 2013) flew mainly poleto-pole over the Pacific Ocean at various times during 2009-2011. Combining data from all five campaigns yields an approximate annual average. The HIPPO data have been screened against contributions from fires, so as to be representative of the background concentration of $\mathrm{BC}$ over the $\mathrm{Pa}$ cific. Two of the HIPPO campaigns also flew over the North American mainland, allowing also for comparisons closer to anthropogenic BC source regions. HIPPO covers atmospheric pressures from surface values up to $100 \mathrm{hPa}$, meaning that its upper range reaches into the lower stratosphere.

The ARCTAS SP2 campaign (Jacob et al., 2010) was flown in two separate time periods in 2008. During spring, flights were conducted over the northern Pacific Ocean, comparable to parts of the HIPPO region, and also over the North Polar regions. During summer, flights were conducted over the North American continent, again comparable to HIPPO. Part of the ARCTAS motivation was to study fires, so the measured concentrations can be expected to have a larger contribution from open biomass burning than the HIPPO data set. ARCTAS data cover the atmospheric segment from the surface up to $250 \mathrm{hPa}$.

The Polar Airborne Measurements and Arctic Regional Climate Model Simulation Project (PAMARCMiP) campaign (Herber et al., 2012; Stone et al., 2010) consisted of a series of flights conducted over the North Polar and Northern Pacific regions, from 2009 through 2012. It covers a vertical range up to $500 \mathrm{hPa}$, and is partially comparable to both ARCTAS and HIPPO. As ARCTAS, PAMARCMiP is partially affected by biomass burning emissions.

Finally, the Aerosol Radiative Forcing in East Asia (AFORCE) aircraft campaign (Oshima et al., 2012) flew over East Asia (southwestern Japan) in spring 2009, covering a vertical range up to $300 \mathrm{hPa}$. It is not regionally comparable to the other campaigns, but is highly relevant because it represents a region dominated by outflow from mainland China, one of the main sources of anthropogenic BC emissions.

\subsection{AeroCom Phase II models}

The models results in the present study come from 13 stateof-the-art aerosol models, submitted as part of Phase II of the AeroCom model intercomparison project (Myhre et al., 2013b; Samset et al., 2013; Schwarz et al., 2013). Participating models are NCAR-CAM3.5 (Lamarque et al., 2012), CAM4-Oslo (Kirkevåg et al., 2013), CAM5.1 (Liu et al., 2012), GISS-MATRIX (Bauer et al., 2010), GISS modelE (Koch et al., 2011), GMI (Bian et al., 2009), GOCARTv4 (Chin et al., 2009), HadGEM2 (Bellouin et al., 2011), IMPACT (Lin et al., 2012), INCA (Szopa et al., 2012), ECHAM5-HAM (Zhang et al., 2012), OsloCTM2 (Skeie et al., 2011) and SPRINTARS (Takemura et al., 2005). See Myhre et al. (2013b) and individual model references for further descriptions.

All models submitted monthly mean 3-D fields of total BC mass mixing ratios, using year 2000 emissions (Lamarque et al., 2010). Meteorological year was 2006, or model internal present-day (PD) climatology. To calculate BC concentrations from mixing ratios, the models' own monthly mean temperature and pressure fields were used. When discussing modifications to the $\mathrm{BC}$ radiative forcing from the direct effect from anthropogenic fossil fuels and biofuels, the models' own monthly mean 2-D forcing fields were used, in combination with a preindustrial simulation using year 1850 emissions but still year 2006 or PD meteorology (Myhre et al., 2013b). For consistency with recent literature, forcing results are given for 1750-2010, using scaling factors presented in Myhre et al. (2013b).

\subsection{Analysis}

To compare flight campaigns and model output, a series of geographical regions were first selected. See Fig. 1. For the flight data, only measurements that fell within the regions were kept, and for each region an average profile was constructed. For the models, all output within the selected region was averaged into a single profile for each model. However, to take the seasonality into account, we produced a model profile for each measurement point or profile from the flights. These were then averaged. The result is a set of model profiles that correspond to the flight profiles both geographically and temporally.

From the concentration profiles, we calculated aerosol burdens for both models and flight data. To ensure comparability, model burdens were calculated only in the same vertical range covered by the flight campaign.

Further, we used the methodology presented in Samset et al. (2013) to calculate BC RF from the concentration profiles. Briefly, we use spatially and temporally resolved normalized forcing efficiency profiles (RF exerted per gram of aerosol at a given altitude) calculated from a single model (Samset and Myhre, 2011), and multiplied with profiles of BC burden per model layer. This yields comparable estimates for total BC 
Table 1. The flight campaigns included in the present work, and the times when they flew.

\begin{tabular}{llll}
\hline Campaign & Region & Time & Data/web site \\
\hline HIPPO 1 & Pacific & January 2009 & http://hippo.ucar.edu/ \\
HIPPO 2 & Pacific & November 2009 & \\
HIPPO 3 & Pacific & March/April 2010 & \\
HIPPO 4 & Pacific & June 2011 & \\
HIPPO 5 & Pacific & August 2011 & \\
A-FORCE & Japan & March/April 2009 & \\
ARCTAS Spring & Northern Pacific, North Polar & April 2008 & http://www-air.larc.nasa.gov/missions \\
ARCTAS Summer & Continental North America & July 2008 & arctas/dataaccess.htm \\
PAMARCMiP 2009 & Northern Pacific, North Polar & April 2009 & \\
PAMARCMiP 2011 & Northern Pacific, North Polar & April 2011 & \\
PAMARCMiP 2012 & North Polar & March-April 2012 & \\
\hline
\end{tabular}

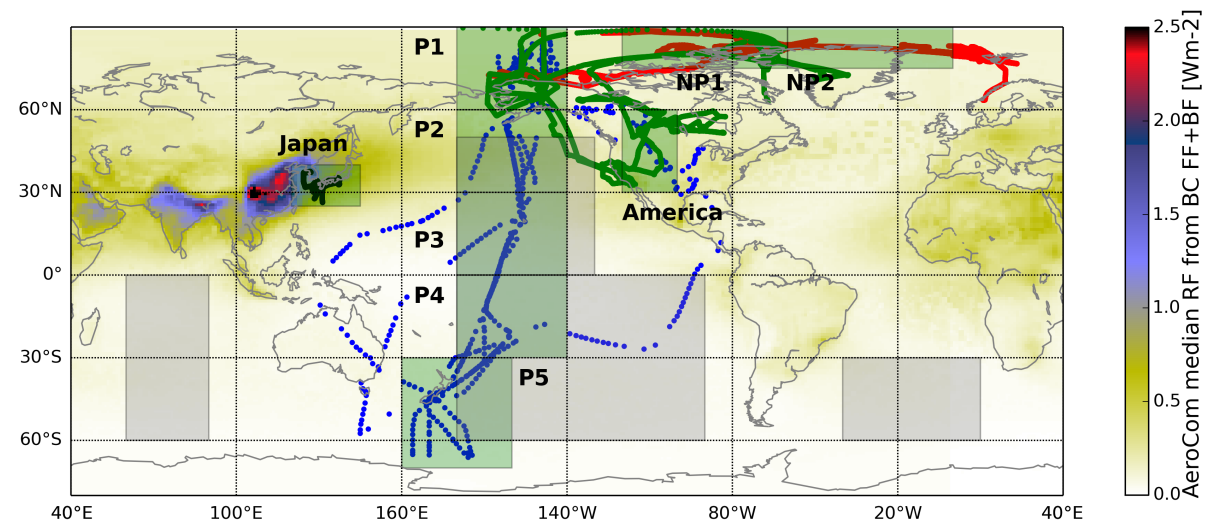

Figure 1. Flight tracks and regions selected for the analysis. Dots represent either single measurements (ARCTAS, A-FORCE, PAMAR$\mathrm{CMiP}$ ) or pre-averaged profiles (HIPPO) from the flight campaigns. Blue: HIPPO. Green: ARCTAS. Red: PAMARCMiP. Black: A-FORCE. Green boxes show the geographical regions where model data were averaged for comparison to the flight profiles. Grey boxes show the areas defined as "remote ocean". The background map shows the median, annual mean RF due to fossil fuel and biofuel burning from the 13 models used in the present study.

forcing within the selected regions, for the seasons covered by the respective flight campaigns; thus all RF calculations are performed with a consistent method. To distinguish the models' own estimates of RF from the RF calculated by this method, we refer to the two as "native RF" and "recalculated RF" respectively. While using the forcing efficiency from a single model (OsloCTM2) will naturally bias the calculated RF towards the forcing strength predicted by that model, it also allows for an estimate of differences in vertical profile shape. Since the forcing efficiency for BC is strongly and monotonically rising with altitude, differences between the overall shape of measured and modelled profiles will cause the ratio of recalculated forcing per burden to differ from unity.

\subsection{Calculation of RMSE values and correlations}

To estimate how well a given model reproduces the Pacific HIPPO flight data, as primarily used below, we calculated model bias, root-mean-square error (RMSE) values and cor- relation coefficients. The HIPPO data set was subdivided into five regions (P1-P5 in Fig. 1), and an annual mean profile was constructed for each region as shown in Fig. 2. For each model, diagnostics were calculated from the difference between the HIPPO concentration profile at each of its given altitude levels, and the regionally averaged model concentration value interpolated to the corresponding altitude, according to the following equations:

$$
\begin{aligned}
\text { Mean bias } & =\frac{1}{N} \sum_{\text {Reg }=P 1}^{P 5} \sum_{\text {Alt }=\text { Surf }}^{\text {TOA }}\left[C_{\text {HIPPO }}(\text { Reg, Alt })\right. \\
& \left.-C_{\text {Model }}(\operatorname{Reg}, \text { Alt })\right]
\end{aligned}
$$

$$
\begin{gathered}
\text { Normalized mean bias }=\frac{1}{N} \sum_{\text {Reg=P1 }}^{P 5} \sum_{\text {Alt }=\text { Surf }}^{\text {TOA }} \\
\frac{\left[C_{\text {HIPPO }}(\text { Reg,Alt })-C_{\text {Model }}(\text { Reg,Alt })\right]}{0.5 \times\left[C_{\text {HIPPO }}(\text { Reg,Alt })+C_{\text {Model }}(\text { Reg, Alt })\right]}
\end{gathered}
$$




\section{Results and discussion}

RMS Error $=$

$$
\sqrt{\frac{1}{N} \sum_{\text {Reg }=P 1}^{P 5} \sum_{\text {Alt }=\text { Surf }}^{\text {TOA }}\left[C_{\text {HIPPO }}(\text { Reg,Alt })-C_{\text {Model }}(\text { Reg,Alt })\right]^{2}} .
$$

Here $C$ denotes a concentration value and $N$ is the total number of data points. In the present case, this value is 72 , determined by the number of altitude bins where HIPPO reported measurements. Further, we calculated the Pearson sample correlation coefficient based on the same data set.

\subsection{Derivation of scaled forcing estimates}

Two scalings were applied in the present work to assess the potential impact of adjusting models to measured BC concentrations. These scalings were derived by altering the 3-D concentration fields of total BC (fossil fuel, biofuel and biomass burning) provided by the AeroCom models, and then applied to the BC FF + BF forcing fields supplied. This method is used to ensure that intermodel variability in $\mathrm{RF}$ due to differences in optical parameters of $\mathrm{BC}$, cloud distributions and other factors related to the host model are kept unchanged.

For the "remote ocean" scaling, the concentration fields were altered within the grey boxes shown in Fig. 1. Between the surface and $500 \mathrm{hPa}$ concentrations were reduced to $1 / 3$, then to $1 / 8$ up to $200 \mathrm{hPa}$, and then to $1 / 15$ up to TOA. These factors were derived from the comparison between AeroCom Phase II and HIPPO 1-5 presented in Schwarz 2013 (Schwarz et al., 2013).

Using the forcing efficiency profile method (Samset and Myhre, 2011), we then calculated global, annual mean BC RF from both scaled and unscaled concentration fields. The ratio of these forcing values is taken as the scaling factor for that particular model.

Finally, we constructed the multimodel median BC $\mathrm{FF}+\mathrm{BF}$ for all 13 models used for the present study, based on their original 2-D forcing fields. These forcing values were scaled with the derived scaling factors, to produce the revised model median forcing.

For the "high altitude" scaling the same procedure was followed, except that the concentration fields were scaled to $1 / 20$ at altitudes between $200 \mathrm{hPa}$ and TOA globally.

For the "all scaled" analysis both scalings were applied to the concentration fields, i.e. the fields were scaled to $1 / 20$ at altitudes between $200 \mathrm{hPa}$ and TOA globally, and then as described above in the grey marked regions at altitudes below $200 \mathrm{hPa}$.

\subsection{Comparisons of flights and models}

Here, we constrain the model range of global, annual mean direct RF by anthropogenic BC, by comparing AeroCom Phase II vertical profiles from 13 models, to recent aircraft campaigns. Figure 1 shows the flight tracks of the four campaigns, the AeroCom multimodel median anthropogenic BC forcing field, and the regions selected for analysis.

Table 2 shows individual model BC RF, recalculated using the forcing efficiency profile method, globally and for the regions in Fig. 1. We also show the fraction of RF above $5 \mathrm{~km}(500 \mathrm{hPa})$,

Figure 2 compares flight campaign data with AeroCom Phase II model output. Panels a-f show the HIPPO1-5 campaigns (Schwarz et al., 2013) for five regions in the remote Pacific Ocean and for western North America, overlain with AeroCom Phase II results. A common pattern is that the models strongly overpredict the HIPPO measurements. Further, the overprediction is more pronounced at high altitudes. Comprised of five campaigns distributed throughout the year, HIPPO represents an approximate annual average. As recently noted (Schwarz et al., 2013), its Pacific measurements indicate that at the highest altitudes studied, BC concentrations converge towards a common background value, here found to be approximately $0.1 \mathrm{ng} \mathrm{m}^{-3}$, with very low seasonality. Here we also find (Fig. 2f) the same background value above western North America.

Panels g-i of Fig. 2 show the ARCTAS (Jacob et al., 2010) campaign, which reports significantly higher concentrations than HIPPO. The models mainly underpredict these observations, linked to the fact that ARCTAS encountered biomass burning BC from episodic forest fires (Wang et al., 2011), which HIPPO did not encounter in this region. A notable feature is that above the fire-dominated segments, the ARCTAS profiles show a strong decline with altitude. In the P1 (Northern Pacific) region upper tropospheric ARCTAS concentrations are similar to those measured in HIPPO.

Panels j-1 show PAMARCMiP (Herber et al., 2012; Stone et al., 2010) data, first over the North Pacific region, and then over two North Polar regions. While the altitude range covered by PAMARCMiP is limited compared to ARCTAS and HIPPO, the concentrations found in the lowest few kilometres of the troposphere are consistent with ARCTAS. Over the NP1 and NP2 region, north of America and Greenland, models underpredict the measurements. As for ARCTAS, this is at least partly due to episodic fires. The Arctic region may however have further sources of $\mathrm{BC}$ not adequately represented in the emission inventories used by the models (Stohl et al., 2013).

Panel $\mathrm{m}$ shows A-FORCE (Oshima et al., 2012) data in the sea areas around Japan. Here we find good agreement between models and measured concentrations, both in absolute values and in the shape of the vertical profile. The variability 

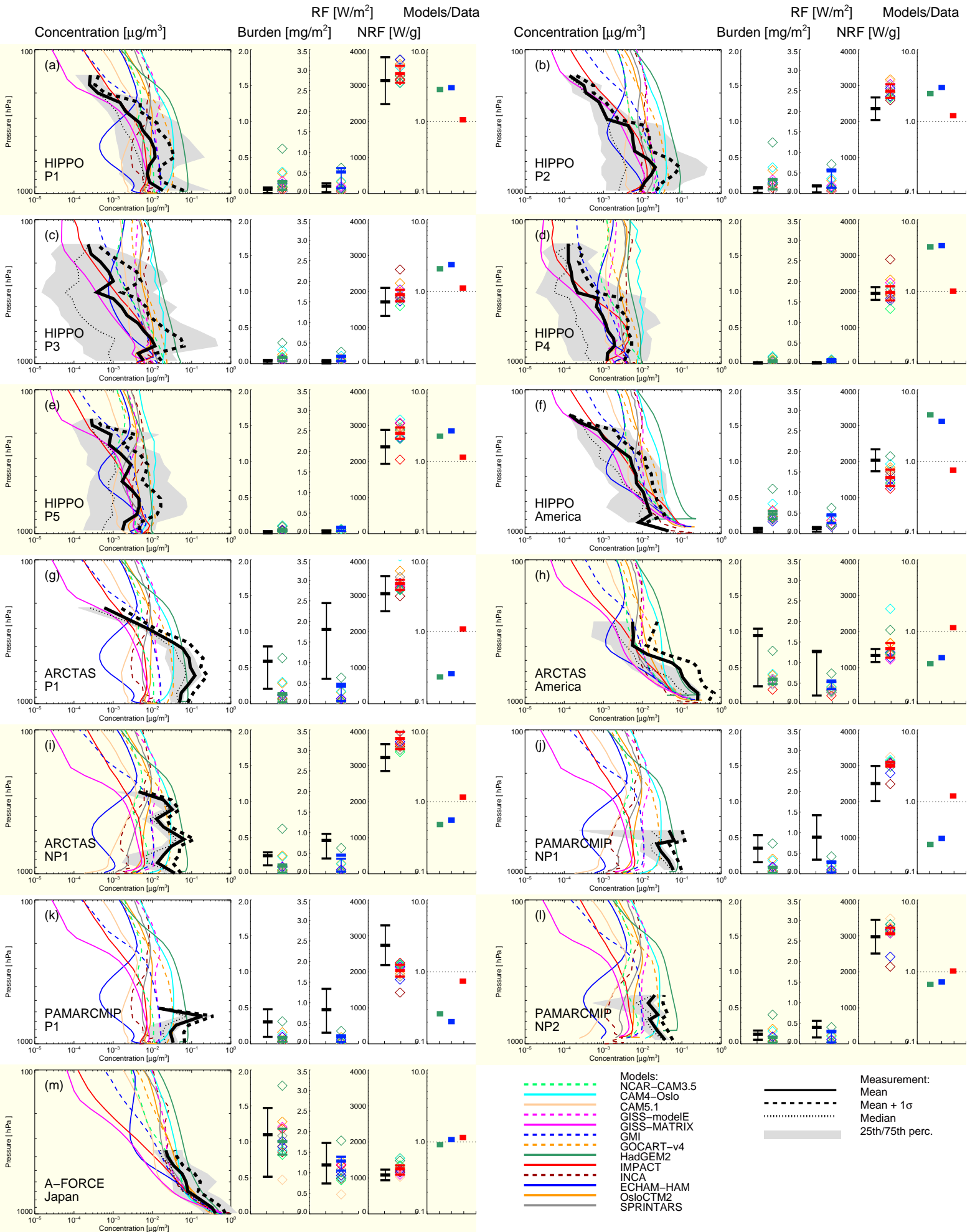

Figure 2. Comparison of measurements and model data for all selected regions. For each panel, the left box shows an overlay of the observed total BC concentration profiles - black lines: mean (solid), median (dotted) and mean +1 standard deviation (dashed), and 25th-75th percentile range (grey band) - with the mean BC concentration profiles from individual AeroCom Phase II models (coloured lines, see legend). The three middle boxes show, from left to right, the BC burden $\left(\mathrm{mg} \mathrm{m}^{-2}\right)$, direct radiative forcing $\left(\mathrm{W} \mathrm{m}^{-2}\right)$ and forcing efficiency $\left(\mathrm{W} \mathrm{g}^{-1}\right)$ for observations (black) and models (red). The coloured diamonds show the individual AeroCom Phase II models. Finally, the rightmost box shows the ratio of models to observations for the burden (green), radiative forcing (blue) and forcing efficiency (red) within the selected region. 
Table 2. Modelled mean forcing and fractions for the regions used in the present analysis (see Fig. 1). Mean RF is the forcing within that region. Fraction of global RF is defined as the fraction of energy deposited, on annual mean, within that region. "Remotes" represents the total of all grey marked regions in Fig. 1.

\begin{tabular}{lrrrr}
\hline Region & Mean RF & $\begin{array}{r}\text { Fraction of } \\
\text { global area }\end{array}$ & $\begin{array}{r}\text { Fraction of } \\
\text { global RF }\end{array}$ & $\begin{array}{r}\text { Fraction of RF } \\
\text { above 200 hPa }\end{array}$ \\
\hline & {$\left[\mathrm{W} \mathrm{m}^{-2}\right]$} & {$[1]$} & {$[1]$} & {$[1]$} \\
\hline Global & 0.26 & 1.00 & 1.00 & 0.24 \\
\hline America & 0.32 & 0.01 & 0.01 & 0.30 \\
Japan & 0.98 & 0.01 & 0.04 & 0.20 \\
P1 & 0.28 & 0.01 & 0.01 & 0.31 \\
P2 & 0.39 & 0.02 & 0.03 & 0.28 \\
P3 & 0.17 & 0.03 & 0.02 & 0.32 \\
P4 & 0.06 & 0.03 & 0.01 & 0.43 \\
P5 & 0.06 & 0.02 & 0.01 & 0.47 \\
NP1 & 0.26 & 0.003 & 0.003 & 0.30 \\
NP2 & 0.25 & 0.003 & 0.003 & 0.31 \\
Remotes & 0.17 & 0.26 & 0.15 & 0.35 \\
\hline
\end{tabular}

between models is also much lower in this region than for the others. The aerosol in the A-FORCE region is mainly sensitive to outflow from mainland China, Korea and Japan. This indicates that in AeroCom Phase II, East Asian BC emissions and outflow are either well represented or, if emissions are still underestimated as discussed for AeroCom Phase I in recent literature (Bond et al., 2013; Chung et al., 2012), the atmospheric lifetime of $\mathrm{BC}$ must be compensatory long in the models to allow enough $\mathrm{BC}$ to be transported into the region sampled by A-FORCE. We note, however, that the A-FORCE data do not extend as far up in the atmosphere as HIPPO did, and that we find significant intermodel variability at $p<400 \mathrm{hPa}$ also for the near-source A-FORCE and HIPPO America regions.

While the aircraft data in the present study were taken over the period 2008-2012, the models used emissions from year 2000. BC emissions have increased in the intervening period (Wang et al., 2014b), indicating that any overestimation of concentrations by the models would have been strengthened had they used a more recent emission inventory. One model (CAM4-Oslo) delivered results for both year 2000 and 2006 emissions, reflecting this increase. In remote regions (e.g. the HIPPO regions in Fig. 1), the resulting increase in concentration is found to be evenly distributed throughout the vertical profile, except in the range $1000-800 \mathrm{hPa}$ where no significant increase was found. It is clear that for future comparisons, model calculations with updated emission inventories are desirable.

\subsection{Consequences for $\mathrm{BC}$ atmospheric lifetime}

In the following, we assess the implications of the flight observations on modelled BC lifetime and RF. Episodic biomass burning emissions from fires, even though repre- sented in the model emissions, pose challenges when comparing flight campaigns to monthly mean model data. Arguably fires are also difficult to characterize as anthropogenic. Below, we therefore constrain our discussion to the HIPPO data set, which was less influenced by episodic fires, reached the highest altitudes, covers the largest geographical area, and represents an approximate annual mean.

Figure 2 shows that some models more closely reproduce the measurements than others, both in magnitude and shape. Several studies have suggested that to reproduce HIPPO data, a low modelled atmospheric lifetime, or a short ageing timescale, of BC is required (Bauer et al., 2013; Wang et al., 2014a). Here we can test this supposition for a larger set of models. Quantifying the difference between models and data requires care, as absolute concentrations range over several orders of magnitude. Common diagnostic variables include model bias and RMS error. Of these, RMS error and model mean bias (see Methods) will be dominated by high absolute concentrations, i.e. low altitudes in the present case. Model mean normalized bias avoids this, but will be more sensitive to model and measurement uncertainties in high altitude, low concentration ranges. In Fig. 3, RMS error and biases are plotted as a function of the modelled BC lifetime. Lifetime, also referred to as atmospheric residence time, is here defined as modelled global, annual mean emissions divided by burden (Table 3 ).

Figure 3 shows that, independent of diagnostic variable, a low $\mathrm{BC}$ lifetime is a requirement for good reproduction of absolute modelled concentrations. Regressing bias or RMS error versus lifetime (black, dashed line in Fig. 3) gives an intercept at 3 days for RMS error and model mean bias. This value is in line with indications from other recent studies, e.g. Bauer et al. (2013). In the present data set, a single model with high lifetime (HadGEM2) represents a 
Table 3. BC FF + BF RF and BC atmospheric lifetime of BC for the models used in the present study. Bias, RMSE and correlation coefficients are for comparisons of each model with HIPPO data for all Pacific regions (P1-P5). Each calculation is based on 72 data points.

\begin{tabular}{lrrrrrr}
\hline Model & BC FF + BF RF & BC Lifetime & RMSE & Correlation & Mean bias & Normalized bias \\
\hline & {$\left[\mathrm{W} \mathrm{m}^{-2}\right]$} & [days] & {$\left[\mathrm{ng} \mathrm{m}^{-3}\right]$} & {$[1]$} & {$\left[\mathrm{ng} \mathrm{m}^{-3}\right]$} & {$[1]$} \\
\hline INCA & 0.18 & 7.1 & 5.6 & 0.12 & 0.002 & 0.79 \\
GOCART & 0.18 & 7.2 & 13.3 & 0.86 & 0.010 & 1.34 \\
OsloCTM2 & 0.28 & 6.0 & 4.7 & 0.64 & 0.003 & 0.87 \\
CAM4-Oslo & 0.37 & 8.2 & 15.9 & 0.72 & 0.014 & 1.44 \\
SPRINTARS & 0.21 & 6.7 & 4.4 & 0.62 & 0.002 & 0.78 \\
ECHAM-HAM & 0.14 & 5.5 & 4.5 & 0.39 & -0.002 & 0.01 \\
HadGEM2 & 0.19 & 17.1 & 34.1 & 0.84 & 0.025 & 1.56 \\
GISS-modelE & 0.21 & 5.9 & 6.1 & 0.67 & 0.004 & 0.87 \\
IMPACT & 0.14 & 3.8 & 2.7 & 0.82 & 0.000 & 0.10 \\
GMI & 0.17 & 4.4 & 4.1 & 0.86 & 0.003 & 0.68 \\
CAM5 & 0.2 & 3.8 & 4.6 & 0.37 & -0.001 & 0.15 \\
NCAR-CAM3.5 & 0.15 & 5.8 & 4.1 & 0.80 & 0.002 & 0.71 \\
GISS-MATRIX & 0.19 & 3.5 & 2.9 & 0.87 & -0.001 & -0.49 \\
\hline
\end{tabular}
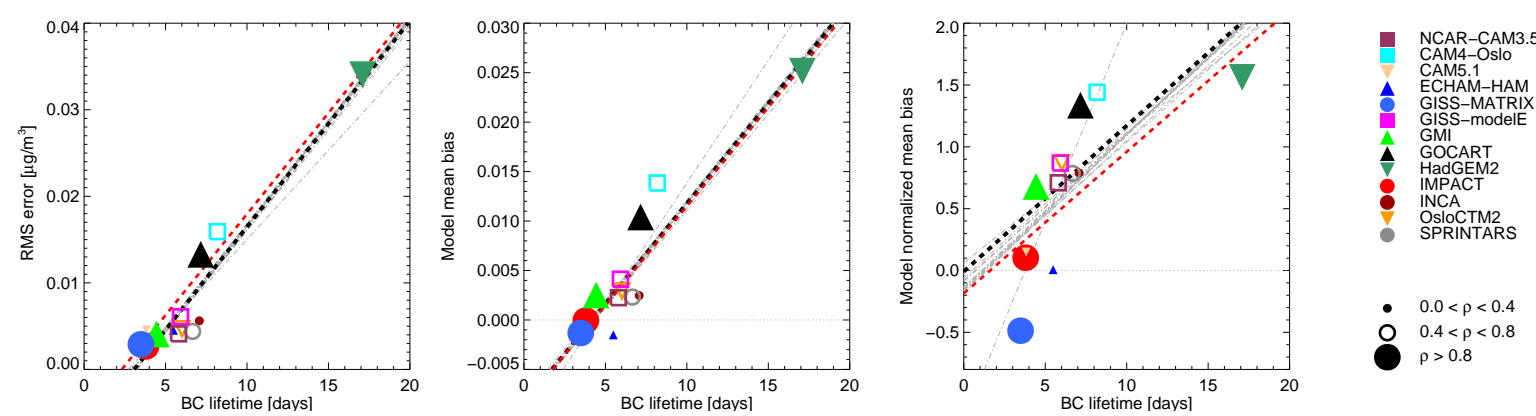

Figure 3. Modelled global BC lifetime plotted versus RMSE, mean bias and normalized mean bias, between model prediction and observations for the five HIPPO regions (P1-P5). Each RMSE or bias calculation is based on 72 data points. The symbol size indicates the corresponding Pearson correlation coefficient. The black dashed line shows a least-squares regression line with all models included. The grey lines show regressions with one model removed. The red dashed line shows a regression using only models with $\rho>0.8$.

significantoutlier. That model did not include BC ageing and transition to a hydrophilic state, with the consequence that both $\mathrm{BC}$ lifetime and burdens over remote areas become high (Bellouin et al., 2011). To test the impacts of single models on the result, Fig. 3 also shows regressions with one model removed (grey lines). For the normalized mean bias, which is less sensitive to high concentrations, the regression with this particular model removed is consistent with the results from RMS error and mean bias.

Bias and RMSE give information on absolute deviations, but less on any covariance in shape. The Pearson correlation coefficient, however, is sensitive to the shape of the BC profiles. In Fig. 3, correlation is indicated by symbol size. (See also values in Table 3.) Several models with low lifetimes also yield low correlations. Regressing only the models with correlation coefficients $\rho>0.8$ gives similar slopes and intercepts to what we find using all models (red, dashed line). We note that 12 out of 13 models show correlation with the Pacific HIPPO data at significance $p>0.05$.
Low BC lifetime appears necessary, but not sufficient, to describe the data. Only three models (IMPACT, GMI, GISS-MATRIX) exhibit both a low bias or RMS error and a high correlation, with no single obvious factor linking their aerosol treatments. AeroCom Phase II models use a wide variety of microphysics schemes (Mann et al., 2014). Meteorology and treatment of $\mathrm{BC}$ aging and wet scavenging also vary, and will impact the vertical profiles (Kipling et al., 2013; Bauer et al., 2013). Further model experiments, in line with the single-model study in Wang et al. (2014a), are required to address the reasons behind the relationship found in Fig. 3.

\subsection{Consequences for modelled BC FF + FB RF}

The three models that best reproduce HIPPO in the Pacific all report consistent and relatively low $\mathrm{BC} F F+\mathrm{BF}$ forcing, exerted close to emission sources as expected from the low lifetime. In these three models very little $\mathrm{BC}$ reaches remote ocean regions, or gets lifted above $500 \mathrm{hPa}$, relative to the other models in the ensemble. While the correspondence to 
HIPPO cannot be used to extract information close to emission sources, it does suggest that scaling down the average modelled forcing aloft and in remote ocean regions has merit.

Compared with HIPPO, the current model ensemble overestimates $\mathrm{BC}$ concentrations at all altitudes in remote regions. The overestimation increases with altitude, and is particularly significant at pressures below $200 \mathrm{hPa}$. Further, Schwarz et al. (2013) suggest that the minimum concentration consistently observed by HIPPO in the upper troposphere, lower stratosphere and tropical transition layer may be a global feature. Interestingly, the models shown here do, on average, reproduce the general feature of a common background level, but with a concentration that is approximately 20 times higher than indicated by HIPPO.

The HIPPO data set allows us to test the possible implications of these observations on the multimodel BC RF from AeroCom Phase II, a key basis for BC forcing recently assessed in the IPCCs AR5. We attempt two scalings of the modelled BC concentration fields, to align them with the HIPPO observations. The first assumes that the vertically resolved ratio between models and observations in the Pacific holds for all remote ocean regions, shown as grey shaded areas in Fig. 1. The second assumes that the supposition of a globally uniform high altitude BC concentration from Schwarz et al. (2013) is true. While the present data set is insufficient to determine if such a supposition is true, it is nevertheless interesting to assess its potential impact to see if efforts to measure high-altitude $\mathrm{BC}$ concentrations should be prioritized. Figure 4 shows the implications of these scalings on the multimodel direct RF due to $\mathrm{BC}$ from fossil fuel and biofuel burning $(\mathrm{BC} F F+\mathrm{BF})$. Unscaled, the multimodel median RF found here is $+0.24[+0.17$ to +0.47$] \mathrm{W} \mathrm{m}^{-2}$. (See Table 3) Applying the remote region scaling reduces the global, annual median BC FF + BF RF to $+0.22[+0.16$ to +0.39$] \mathrm{W} \mathrm{m}^{-2}$. The high-altitude scaling reduces it to $+0.19[+0.15$ to +0.33$] \mathrm{W} \mathrm{m}^{-2}$. Applying both simultaneously, while ensuring that we do not doubly scale in remote, high-altitude regions, yields a $\mathrm{BC} \mathrm{FF}+\mathrm{BF} \mathrm{RF}$ of +0.17 $[+0.13$ to +0.28$] \mathrm{W} \mathrm{m}^{-2}$, or a reduction of $25 \%$ from the AeroCom Phase II value combined with a strong reduction in the model spread.

A $25 \%$ reduction in the direct $\mathrm{RF}$ of $\mathrm{BC}$ would have significant implications, placing the entire model based 5-95\% range below the central $\mathrm{BC} \mathrm{RF}$ value recently reported in IPCC AR5 (Boucher et al., 2013). Presently, the remaining uncertainty in BC forcing is heavily driven by scalings such as the ones attempted above. The IPCC AR5 assessment took input both from AeroCom Phase II and other studies. One of these studies (Bond et al., 2013) reported a significantly stronger forcing of $0.51 \mathrm{~W} \mathrm{~m}^{-2}$ from fossil fuel and biomass burning. That estimate includes both a gross $15 \%$ global downscaling of BC forcing efficiency due to overestimation of $\mathrm{BC}$ aloft, and a differentiated regional upscaling of emissions derived by comparing aerosol absorption optical depth from AeroCom Phase I with that from AERONET

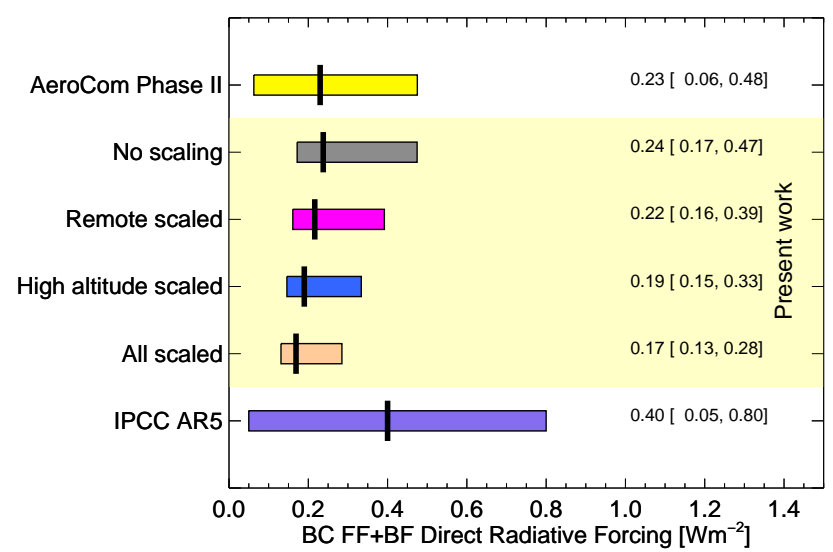

Figure 4. Model median and 5-95\% range for $\mathrm{BC}$ FF $+\mathrm{BF}$ forcing, for 1750-2010, with various scalings applied. The yellow bar shows the AeroCom Phase II result (Myhre et al., 2013b). The grey bar shows unscaled values from the present work, then with remote scaling (pink) and high-altitude scaling (blue) applied. The khaki bar shows the lower limit on $\mathrm{BC} F F+\mathrm{BF}$ forcing from the present work, with both scalings applied. Below we compare with the recent estimate in IPCC WG1's AR5.

ground-based remote sensing. Their downscaling, based on recent model studies (Bond et al., 2013; Samset and Myhre, 2011; Zarzycki and Bond, 2010) and evaluation of AeroCom Phase I results (Schwarz et al., 2010), is comparable to our $25 \%$ reduction in forcing, though our reduction is attributed to remote ocean areas. For near-source and remote regions covered in the present study we here find no need for an emission bias-related upscaling; however the present data do not cover the regions where the upscaling in that analysis (Bond et al., 2013) was most pronounced. Also, the median anthropogenic BC RF in AeroCom Phase II is already a factor of 2 stronger than in Phase I, in part due to differences in emissions and modelled aerosol optical properties (Myhre et al. 2013 b). We note that the above conclusions are broadly consistent with recent findings using the GEOS-Chem model, which is not represented in the present data set (Wang et al., 2014a). It is clear that further observations of BC concentrations, vertically resolved and both in situ and remote, are imperative for constraining the $\mathrm{RF}$ of $\mathrm{BC}$.

\subsection{Applicability of scaling factors derived from total $\mathrm{BC}$ to $\mathrm{BC}$ FF + BF fields}

A question raised by the scaling analysis is whether we bias the results by deriving scaling factors based on total $\mathrm{BC}$ fields, and subsequently applying them to $\mathrm{BC} \mathrm{FF}+\mathrm{BF}$ forcing. At present, no measurement exists that can determine systematic differences between the global distributions of total BC and BC from fossil fuel and biofuel burning. However four of the models participating here (OsloCTM2, CAM3, CAM5 and IMPACT) also supplied full 3-D concentration 

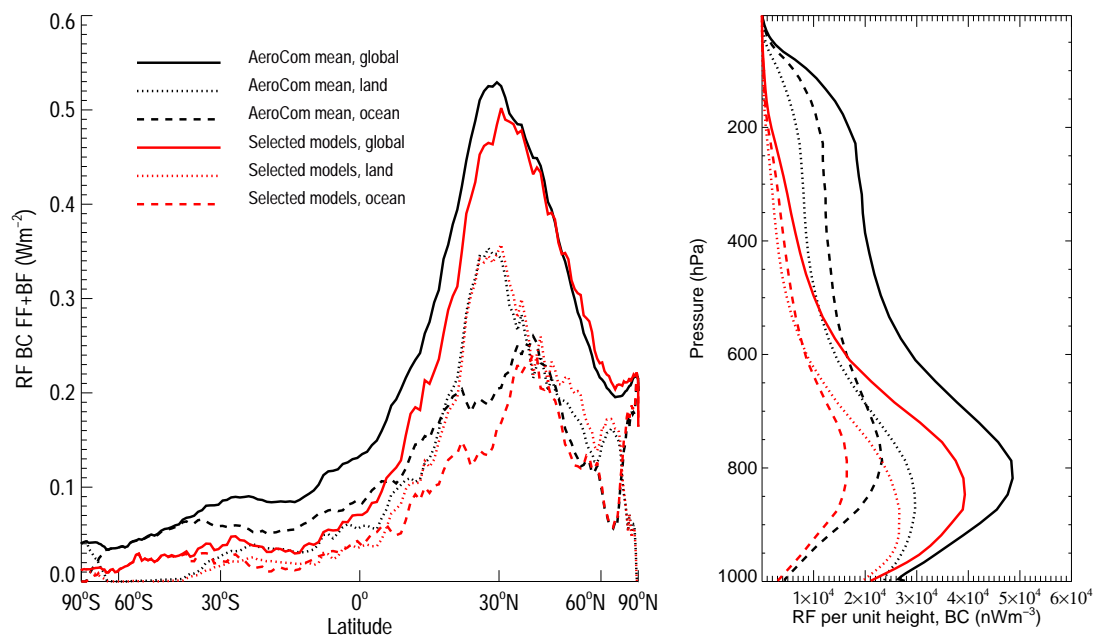

Figure 5. Zonal mean and altitude forcing profiles for AeroCom Phase II models. (a) BC FF + BF forcing, zonal mean, for all 13 models in the present study (black, solid), and the three models selected based on RMSE and correlation versus HIPPO (red, solid). Dotted lines show only forcing over land, dashed show forcing over ocean. (b) As a, except total BC (FF+ BF+BB) forcing, and global, annual mean vertical profile. Forcing is shown per altitude metre (unit $\mathrm{Wm}^{-3}$ ), to avoid dependence on model vertical structure.

fields from BC FF + BF only, and we have used these to test the applicability of the method.

For this subset of models, which spans the range of predicted $\mathrm{BC}$ burdens, we found the ratio of modelled anthropogenic $\mathrm{BC} \mathrm{FF}+\mathrm{BF}$ to total $\mathrm{BC}$ concentrations to be approximately constant with altitude in the regions defined as remote. While trends exist for individual models in single regions, for the remote regions as a whole the ratio changes by less than $10 \%$ through the atmospheric column. Hence any alteration of the $\mathrm{BC}$ vertical profile should equally affect both fields. Further, the fraction of the total global mean forcing found to be exerted at altitudes above $200 \mathrm{hPa}$ was, for these models, found to be comparable for total $\mathrm{BC}$ and $\mathrm{BC}$ FF + BF. (See Table 2.)

These two observations lead us to conclude that we do not strongly bias our results by applying scaling factors derived from total $\mathrm{BC}$ fields to $\mathrm{BC} \mathrm{FF}+\mathrm{BF}$ forcing.

\subsection{Forcing pattern from models with low RMS and good correlation with HIPPO}

We have shown that of the models participating in the present comparison, there are three (GMI, GISS-MATRIX, IMPACT) that both show a low RMSE and a good correlation with the Pacific HIPPO data. These three models all have low global mean atmospheric lifetimes of $\mathrm{BC}$, and report among the lowest BC FF + BF RF values in the AeroCom Phase II ensemble.

Figure 5 shows the zonal mean $\mathrm{BC} \mathrm{FF}+\mathrm{BF} \mathrm{RF}$, and total $\mathrm{BC}$ forcing density (RF per unit height) vertical profile, from the full model ensemble, and from the three HIPPOcorresponding models only. Total BC is used for the vertical profile as not all models provided full 3-D concentra- tion fields, as outlined above. The obvious feature is that for these three models, forcing is exerted primarily closer to the sources, and at lower altitudes, than in the full ensemble. Very little is exerted in the Southern Ocean, or above $200 \mathrm{hPa}$.

Figure 6 shows the results from the scaling analysis above, compared with results for the three HIPPO-corresponding models only. From the outset they have low forcing, and the scaling exercise does not significantly affect them as there is already very little forcing in the scaled regions. The final model median, however, is consistent with that from the scaled full model ensemble. This gives a separate indication that a reduction of $25 \%$ in anthropogenic $\mathrm{BC}$ RF relative to the AeroCom Phase II value is reasonable if we take the HIPPO Pacific measurements as guidance.

\section{Conclusions}

We have compared recent aircraft-based measurements of BC concentration with state-of-the-art global aerosol-climate models. In remote regions where BC concentration are dominated by long-range transport, and at high altitudes, there is a tendency for the models to overestimate the aircraft measurements, where and when the effects of fires are small. For a region sensitive to Asian emission sources, models reproduce the aircraft measurements remarkably well, with no indication of an underestimation in $\mathrm{BC}$ emissions. In remote ocean regions, an atmospheric lifetime of anthropogenic $\mathrm{BC}$ of less than 5 days seems crucial, but not sufficient, to be able to reproduce measurement data. Scaling the multimodel results to HIPPO measurements, remotely and aloft, and assuming a globally 


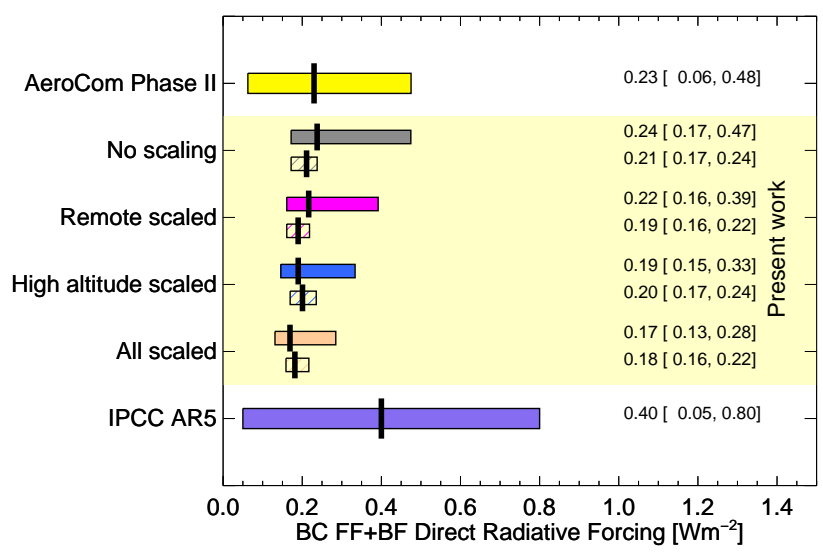

Figure 6. As Fig. 4, except also showing the BC FF + BF forcing from the three models selected based on RMSE and correlation versus HIPPO (hatched boxes).

uniform high-altitude $\mathrm{BC}$ concentration, leads to a reduction of $25 \%$ in anthropogenic $\mathrm{BC}$ direct $\mathrm{RF}$, relative to the models native values. The revised median of $0.17 \mathrm{~W} \mathrm{~m}^{-2}$ stands in stark contrast to recent assessments, which report up to 2-3 times stronger present-day $\mathrm{BC}$ forcing, but is in line with recent single-model studies (Wang et al., 2014a; Bauer et al., 2013). This discrepancy underlines the impact of combining measured $\mathrm{BC}$ concentration data with model estimates. To resolve these differences, and better constrain the climate impact of $\mathrm{BC}$, there is an urgent need for further flight campaigns to provide $\mathrm{BC}$ vertical concentration profiles over both source regions, and regions where anthropogenic BC concentrations are dominated by transport and wet scavenging.

Acknowledgements. B. H. Samset, G. Myhre and M. Schulz were supported by the Research Council of Norway, through the grants SLAC, AEROCOM-P3 and EarthClim, and the EC Seventh Framework Programme under grant agreement FP7-ENV-2011282688 (ECLIPSE). R. C. Easter, S. J. Ghan, X. Liu and K. Zhang were supported by the Scientific Discovery through Advanced Computing (SciDAC) program funded by the US Department of Energy Office of Advanced Scientific Computing Research and Office of Biological and Environmental Research. The Pacific Northwest National Laboratory (PNNL) is operated for the DOE by Battelle Memorial Institute under contract DE-AC06-76RLO 1830. P. Stier's research has been supported by the European Research Council under the European Union's Seventh Framework Programme (FP7/2007-2013)/ERC grant agreement no. FP7-280025 and by the UK NERC project GASSP (NE/J022624/1). S. E. Bauer was supported by the NASA MAP program (NN-H-04-Z-YS-008$\mathrm{N}$ and NN-H-08-Z-DA-001-N). Resources supporting this work were provided by the NASA High-End Computing (HEC) Program through the NASA Center for Climate Simulation (NCCS). T. Iversen, A. Kirkevåg and $\varnothing$. Seland were supported by the Research Council of Norway through the EarthClim (207711/E10) and NOTUR/NorStore projects, CRAICC, and through the EU projects PEGASOS and ACCESS. A. Kirkevåg also received funding from the Norwegian Space Center through the PM-VRAE project. The National Center for Atmospheric Research is operated by the University Corporation for Atmospheric Research under sponsorship of the National Science Foundation. N. Bellouin was supported by the Joint DECC/Defra Met Office Hadley Centre Climate Programme (GA01101). Y. Kondo, N. Moteki, M. Koike, and N. Oshima were supported by the Global Environment Research Fund of the Ministry of the Environment, Japan (A-0803, A-1101, and 2-1403) and the Japan Society for the Promotion of Science (JSPS) KAKENHI Grant Numbers 23221001 and 26701004.

Edited by: M. Kanakidou

\section{References}

Ban-Weiss, G. A., Cao, L., Bala, G., and Caldeira, K.: Dependence of climate forcing and response on the altitude of black carbon aerosols, Clim. Dynam., 38, 897-911, doi:10.1007/s00382-0111052-y, 2011.

Bauer, S. E., Menon, S., Koch, D., Bond, T. C., and Tsigaridis, K.: A global modeling study on carbonaceous aerosol microphysical characteristics and radiative effects, Atmos. Chem. Phys., 10, 7439-7456, doi:10.5194/acp-10-7439-2010, 2010.

Bauer, S. E., Bausch, A., Nazarenko, L., Tsigaridis, K., Xu, B. Q., Edwards, R., Bisiaux, M., and McConnell, J.: Historical and future black carbon deposition on the three ice caps: Ice core measurements and model simulations from 1850 to 2100 , J. Geophys. Res.-Atmos., 118, 7948-7961, doi:10.1002/Jgrd.50612, 2013.

Bellouin, N., Rae, J., Jones, A., Johnson, C., Haywood, J., and Boucher, O.: Aerosol forcing in the Climate Model Intercomparison Project (CMIP5) simulations by HadGEM2-ES and the role of ammonium nitrate, J. Geophys. Res.-Atmos., 116, D20206, doi:10.1029/2011jd016074, 2011.

Bian, H., Chin, M., Rodriguez, J. M., Yu, H., Penner, J. E., and Strahan, S.: Sensitivity of aerosol optical thickness and aerosol direct radiative effect to relative humidity, Atmos. Chem. Phys., 9, 2375-2386, doi:10.5194/acp-9-2375-2009, 2009.

Bond, T. C., Doherty, S. J., Fahey, D. W., Forster, P. M., Berntsen, T., DeAngelo, B. J., Flanner, M. G., Ghan, S., Kärcher, B., Koch, D., Kinne, S., Kondo, Y., Quinn, P. K., Sarofim, M. C., Schultz, M. G., Schulz, M., Venkataraman, C., Zhang, H., Zhang, S., Bellouin, N., Guttikunda, S. K., Hopke, P. K., Jacobson, M. Z., Kaiser, J. W., Klimont, Z., Lohmann, U., Schwarz, J. P., Shindell, D., Storelvmo, T., Warren, S. G., and Zender, C. S.: Bounding the role of black carbon in the climate system: A scientific assessment, J. Geophys. Res.-Atmos., 118, 5380-5552, doi:10.1002/jgrd.50171, 2013.

Boucher, O., Randall, D., Artaxo, P., Bretherton, C., Feingold, G., Forster, P., Kerminen, V.-M., Kondo, Y., Liao, H., Lohmann, U., Rasch, P., Satheesh, S. K., Sherwood, S., Stevens, B., and Zhang, X. Y.: Clouds and Aerosols. In: Climate Change 2013: The Physical Science Basis. Contribution of Working Group I to the Fifth Assessment Report of the Intergovernmental Panel on Climate Change, edited by: Stocker, T. F., Qin, D., Plattner, G.-K., Tignor, M., Allen, S.K., Boschung, J., Nauels, A., Xia, Y., Bex, V., and Midgley, P. M., Cambridge University Press, Cambridge, United Kingdom and New York, NY, USA, 571-658, 2013. 
Chin, M., Diehl, T., Dubovik, O., Eck, T. F., Holben, B. N., Sinyuk, A., and Streets, D. G.: Light absorption by pollution, dust, and biomass burning aerosols: a global model study and evaluation with AERONET measurements, Ann. Geophys., 27, 3439-3464, doi:10.5194/angeo-27-3439-2009, 2009.

Chung, C. E., Ramanathan, V., and Decremer, D.: Observationally constrained estimates of carbonaceous aerosol radiative forcing, P. Natl. Acad. Sci. USA, 109, 11624-11629, doi:10.1073/pnas.1203707109, 2012.

Flanner, M. G.: Arctic climate sensitivity to local black carbon, J. Geophys. Res.-Atmos., 118, 1840-1851, doi:10.1002/Jgrd.50176, 2013.

Haywood, J. M. and Shine, K. P.: The Effect of Anthropogenic Sulfate and Soot Aerosol on the Clear-Sky Planetary Radiation Budget, Geophys. Res. Lett., 22, 603-606, 1995.

Herber, A. B., Haas, C., Stone, R. S., Bottenheim, J. W., Liu, P., Li, S.-M., Staebler, R. M., Strapp, J. W., and Dethloff, K.: Regular airborne surveys of Arctic sea ice and atmosphere, Eos, Transactions American Geophysical Union, 93, 41-42, doi:10.1029/2012eo040001, 2012.

Hodnebrog, O., Myhre, G., and Samset, B. H.: How shorter black carbon lifetime alters its climate effect, Nature Communications, 5, 5065, doi:10.1038/ncomms6065, 2014.

Jacob, D. J., Crawford, J. H., Maring, H., Clarke, A. D., Dibb, J. E., Emmons, L. K., Ferrare, R. A., Hostetler, C. A., Russell, P. B., Singh, H. B., Thompson, A. M., Shaw, G. E., McCauley, E., Pederson, J. R., and Fisher, J. A.: The Arctic Research of the Composition of the Troposphere from Aircraft and Satellites (ARCTAS) mission: design, execution, and first results, Atmos. Chem. Phys., 10, 5191-5212, doi:10.5194/acp-10-5191-2010, 2010.

Kipling, Z., Stier, P., Schwarz, J. P., Perring, A. E., Spackman, J. R., Mann, G. W., Johnson, C. E., and Telford, P. J.: Constraints on aerosol processes in climate models from vertically-resolved aircraft observations of black carbon, Atmos. Chem. Phys., 13, 5969-5986, doi:10.5194/acp-13-5969-2013, 2013.

Kirkevåg, A., Iversen, T., Seland, Ø., Hoose, C., Kristjánsson, J. E., Struthers, H., Ekman, A. M. L., Ghan, S., Griesfeller, J., Nilsson, E. D., and Schulz, M.: Aerosol-climate interactions in the Norwegian Earth System Model - NorESM1-M, Geosci. Model Dev., 6, 207-244, doi:10.5194/gmd-6-207-2013, 2013.

Koch, D., Bauer, S. E., Del Genio, A., Faluvegi, G., McConnell, J. R., Menon, S., Miller, R. L., Rind, D., Ruedy, R., Schmidt, G. A., and Shindell, D.: Coupled Aerosol-Chemistry-Climate Twentieth-Century Transient Model Investigation: Trends in Short-Lived Species and Climate Responses, J. Climate, 24, 2693-2714, doi:10.1175/2011jcli3582.1, 2011.

Koffi, B., Schulz, M., Breon, F. M., Griesfeller, J., Winker, D., Balkanski, Y., Bauer, S., Berntsen, T., Chin, M. A., Collins, W. D., Dentener, F., Diehl, T., Easter, R., Ghan, S., Ginoux, P., Gong, S. L., Horowitz, L. W., Iversen, T., Kirkevag, A., Koch, D., Krol, M., Myhre, G., Stier, P., and Takemura, T.: Application of the CALIOP layer product to evaluate the vertical distribution of aerosols estimated by global models: AeroCom phase I results, J. Geophys. Res.-Atmos., 117, D10201, doi:10.1029/2011jd016858, 2012.

Kondo, Y., Sahu, L., Moteki, N., Khan, F., Takegawa, N., Liu, X., Kolke, M., and Miyakawa, T.: Consistency and Traceability of Black Carbon Measurements Made by Laser-Induced Incandescence, Thermal-Optical Transmittance, and Filter-Based
Photo-Absorption Techniques, Aerosol Sci. Tech., 45, 295-312, doi:10.1080/02786826.2010.533215, 2011.

Lamarque, J.-F., Bond, T. C., Eyring, V., Granier, C., Heil, A., Klimont, Z., Lee, D., Liousse, C., Mieville, A., Owen, B., Schultz, M. G., Shindell, D., Smith, S. J., Stehfest, E., Van Aardenne, J., Cooper, O. R., Kainuma, M., Mahowald, N., McConnell, J. R., Naik, V., Riahi, K., and van Vuuren, D. P.: Historical (1850-2000) gridded anthropogenic and biomass burning emissions of reactive gases and aerosols: methodology and application, Atmos. Chem. Phys., 10, 7017-7039, doi:10.5194/acp10-7017-2010, 2010.

Lamarque, J.-F., Emmons, L. K., Hess, P. G., Kinnison, D. E., Tilmes, S., Vitt, F., Heald, C. L., Holland, E. A., Lauritzen, P. H., Neu, J., Orlando, J. J., Rasch, P. J., and Tyndall, G. K.: CAM-chem: description and evaluation of interactive atmospheric chemistry in the Community Earth System Model, Geosci. Model Dev., 5, 369-411, doi:10.5194/gmd-5-369-2012, 2012.

Lin, G., Penner, J. E., Sillman, S., Taraborrelli, D., and Lelieveld, J.: Global modeling of SOA formation from dicarbonyls, epoxides, organic nitrates and peroxides, Atmos. Chem. Phys., 12, 4743-4774, doi:10.5194/acp-12-4743-2012, 2012.

Liu, X., Easter, R. C., Ghan, S. J., Zaveri, R., Rasch, P., Shi, X., Lamarque, J.-F., Gettelman, A., Morrison, H., Vitt, F., Conley, A., Park, S., Neale, R., Hannay, C., Ekman, A. M. L., Hess, P., Mahowald, N., Collins, W., Iacono, M. J., Bretherton, C. S., Flanner, M. G., and Mitchell, D.: Toward a minimal representation of aerosols in climate models: description and evaluation in the Community Atmosphere Model CAM5, Geosci. Model Dev., 5, 709-739, doi:10.5194/gmd-5-709-2012, 2012.

Mann, G. W., Carslaw, K. S., Reddington, C. L., Pringle, K. J., Schulz, M., Asmi, A., Spracklen, D. V., Ridley, D. A., Woodhouse, M. T., Lee, L. A., Zhang, K., Ghan, S. J., Easter, R. C., Liu, X., Stier, P., Lee, Y. H., Adams, P. J., Tost, H., Lelieveld, J., Bauer, S. E., Tsigaridis, K., van Noije, T. P. C., Strunk, A., Vignati, E., Bellouin, N., Dalvi, M., Johnson, C. E., Bergman, T., Kokkola, H., von Salzen, K., Yu, F., Luo, G., Petzold, A., Heintzenberg, J., Clarke, A., Ogren, J. A., Gras, J., Baltensperger, U., Kaminski, U., Jennings, S. G., O’Dowd, C. D., Harrison, R. M., Beddows, D. C. S., Kulmala, M., Viisanen, Y., Ulevicius, V., Mihalopoulos, N., Zdimal, V., Fiebig, M., Hansson, H.-C., Swietlicki, E., and Henzing, J. S.: Intercomparison and evaluation of global aerosol microphysical properties among AeroCom models of a range of complexity, Atmos. Chem. Phys., 14, 4679-4713, doi:10.5194/acp-14-4679-2014, 2014.

Myhre, G., Myhre, C. E. L., Samset, B. H., and Storelvmo, T.: Aerosols and their Relation to Global Climate and Climate Sensitivity, Nature Knowledge Project, 4(5):7, available at: http://www.nature.com/scitable/knowledge/library/ aerosols-and-their-relation-to-global-climate-102215345 2013a.

Myhre, G., Samset, B. H., Schulz, M., Balkanski, Y., Bauer, S., Berntsen, T. K., Bian, H., Bellouin, N., Chin, M., Diehl, T., Easter, R. C., Feichter, J., Ghan, S. J., Hauglustaine, D., Iversen, T., Kinne, S., Kirkevåg, A., Lamarque, J.-F., Lin, G., Liu, X., Lund, M. T., Luo, G., Ma, X., van Noije, T., Penner, J. E., Rasch, P. J., Ruiz, A., Seland, Ø., Skeie, R. B., Stier, P., Takemura, T., Tsigaridis, K., Wang, P., Wang, Z., Xu, L., Yu, H., Yu, F., Yoon, J.-H., Zhang, K., Zhang, H., and Zhou, C.: Radiative forcing of 
the direct aerosol effect from AeroCom Phase II simulations, Atmos. Chem. Phys., 13, 1853-1877, doi:10.5194/acp-13-18532013, 2013b.

Oshima, N., Kondo, Y., Moteki, N., Takegawa, N., Koike, M., Kita, K., Matsui, H., Kajino, M., Nakamura, H., Jung, J. S., and Kim, Y. J.: Wet removal of black carbon in Asian outflow: Aerosol Radiative Forcing in East Asia (A-FORCE) aircraft campaign, J. Geophys. Res., 117, D03204, doi:10.1029/2011jd016552, 2012.

Ramanathan, V. and Carmichael, G.: Global and regional climate changes due to black carbon, Nat. Geosci., 1, 221-227, doi:10.1038/Ngeo156, 2008.

Samset, B. H. and Myhre, G.: Vertical dependence of black carbon, sulphate and biomass burning aerosol radiative forcing, Geophys. Res. Lett., 38, L24802, doi:10.1029/2011g1049697, 2011.

Samset, B. H., Myhre, G., Schulz, M., Balkanski, Y., Bauer, S., Berntsen, T. K., Bian, H., Bellouin, N., Diehl, T., Easter, R. C., Ghan, S. J., Iversen, T., Kinne, S., Kirkevåg, A., Lamarque, J.F., Lin, G., Liu, X., Penner, J. E., Seland, Ø., Skeie, R. B., Stier, P., Takemura, T., Tsigaridis, K., and Zhang, K.: Black carbon vertical profiles strongly affect its radiative forcing uncertainty, Atmos. Chem. Phys., 13, 2423-2434, doi:10.5194/acp-13-24232013, 2013.

Samset, B. H., Myhre, G., and Schulz, M.: Upward adjustment needed for aerosol radiative forcing uncertainty, Nat. Clim. Change, 4, 230-232, 10.1038/nclimate2170, 2014.

Schwarz, J. P., Spackman, J. R., Gao, R. S., Watts, L. A., Stier, P., Schulz, M., Davis, S. M., Wofsy, S. C., and Fahey, D. W.: Global scale black carbon profiles observed in the remote atmosphere and compared to models, Geophys. Res. Lett., 37, L18812, doi:10.1029/2010GL044372, 2010.

Schwarz, J. P., Samset, B. H., Perring, A. E., Spackman, J. R., Gao, R. S., Stier, P., Schulz, M., Moore, F. L., Ray, E. A., and Fahey, D. W.: Global-scale seasonally resolved black carbon vertical profiles over the Pacific, Geophys. Res. Lett., 40, 5542-5547, doi:10.1002/2013g1057775, 2013.

Skeie, R. B., Berntsen, T., Myhre, G., Pedersen, C. A., Ström, J., Gerland, S., and Ogren, J. A.: Black carbon in the atmosphere and snow, from pre-industrial times until present, Atmos. Chem. Phys., 11, 6809-6836, doi:10.5194/acp-11-6809-2011, 2011.

Stohl, A., Klimont, Z., Eckhardt, S., Kupiainen, K., Shevchenko, V. P., Kopeikin, V. M., and Novigatsky, A. N.: Black carbon in the Arctic: the underestimated role of gas flaring and residential combustion emissions, Atmos. Chem. Phys., 13, 8833-8855, doi:10.5194/acp-13-8833-2013, 2013.

Stone, R. S., Herber, A., Vitale, V., Mazzola, M., Lupi, A., Schnell, R. C., Dutton, E. G., Liu, P. S. K., Li, S. M., Dethloff, K., Lampert, A., Ritter, C., Stock, M., Neuber, R., and Maturilli, M.: A three-dimensional characterization of Arctic aerosols from airborne Sun photometer observations: PAM-ARCMIP, April 2009, J. Geophys. Res., 115, D03203, doi:10.1029/2009jd013605, 2010.
Szopa, S., Balkanski, Y., Schulz, M., Bekki, S., Cugnet, D., Fortems-Cheiney, A., Turquety, S., Cozic, A., Déandreis, C., Hauglustaine, D., Idelkadi, A., Lathière, J., Lefevre, F., Marchand, M., Vuolo, R., Yan, N., and Dufresne, J. L.: Aerosol and ozone changes as forcing for climate evolution between 1850 and 2100, Clim. Dynam., 40, 2223-2250, doi:10.1007/s00382-0121408-y, 2012.

Takemura, T., Nozawa, T., Emori, S., Nakajima, T. Y., and Nakajima, T.: Simulation of climate response to aerosol direct and indirect effects with aerosol transport-radiation model, J. Geophys. Res.-Atmos., 110, D02202, doi:10.1029/2004jd005029, 2005.

Textor, C., Schulz, M., Guibert, S., Kinne, S., Balkanski, Y., Bauer, S., Berntsen, T., Berglen, T., Boucher, O., Chin, M., Dentener, F., Diehl, T., Feichter, J., Fillmore, D., Ginoux, P., Gong, S., Grini, A., Hendricks, J., Horowitz, L., Huang, P., Isaksen, I. S. A., Iversen, T., Kloster, S., Koch, D., Kirkevåg, A., Kristjansson, J. E., Krol, M., Lauer, A., Lamarque, J. F., Liu, X., Montanaro, V., Myhre, G., Penner, J. E., Pitari, G., Reddy, M. S., Seland, Ø., Stier, P., Takemura, T., and Tie, X.: The effect of harmonized emissions on aerosol properties in global models an AeroCom experiment, Atmos. Chem. Phys., 7, 4489-4501, doi:10.5194/acp-7-4489-2007, 2007.

Wang, Q., Jacob, D. J., Fisher, J. A., Mao, J., Leibensperger, E. M., Carouge, C. C., Le Sager, P., Kondo, Y., Jimenez, J. L., Cubison, M. J., and Doherty, S. J.: Sources of carbonaceous aerosols and deposited black carbon in the Arctic in winterspring: implications for radiative forcing, Atmos. Chem. Phys., 11, 12453-12473, doi:10.5194/acp-11-12453-2011, 2011.

Wang, Q., Jacob, D. J., Spackman, J. R., Perring, A. E., Schwarz, J. P., Moteki, N., Marais, E. A., Ge, C., Wang, J., and Barrett, S. R. H.: Global budget and radiative forcing of black carbon aerosol: Constraints from pole-to-pole (HIPPO) observations across the Pacific, J. Geophys. Res.-Atmos., 119, 195-206, doi:10.1002/2013jd020824, 2014a.

Wang, R., Tao, S., Shen, H. Z., Huang, Y., Chen, H., Balkanski, Y., Boucher, O., Ciais, P., Shen, G. F., Li, W., Zhang, Y. Y., Chen, Y. C., Lin, N., Su, S., Li, B. G., Liu, J. F., and Liu, W. X.: Trend in Global Black Carbon Emissions from 1960 to 2007, Environ. Sci. Technol., 48, 6780-6787, 2014b.

Zarzycki, C. M. and Bond, T. C.: How much can the vertical distribution of black carbon affect its global direct radiative forcing?, Geophys. Res. Lett., 37, L20807, doi:10.1029/2010g1044555, 2010.

Zhang, K., O’Donnell, D., Kazil, J., Stier, P., Kinne, S., Lohmann, U., Ferrachat, S., Croft, B., Quaas, J., Wan, H., Rast, S., and Feichter, J.: The global aerosol-climate model ECHAM-HAM, version 2: sensitivity to improvements in process representations, Atmos. Chem. Phys., 12, 8911-8949, doi:10.5194/acp-12-89112012, 2012. 